\title{
THE IMPACT OF MARKETING ON ORNAMENTAL PLANT PRODUCTION BUSINESSES IN KOSOVO
}

\author{
Isuf Lushi $^{1^{*}}$, Besnike Aliaj ${ }^{1}$ \\ 1*Faculty of Life and Environmental Sciences University "Ukshin Hoti” Prizren (UPZ), Kosovo; \\ "Corresponding Author Isuf Lushi, e-mail: isuf.lushi@uni-prizren.com;
}

Received June 2019; Accepted August 2019; Published October 2019;

DOI: https://doi.org/10.31407/ijees9418

\begin{abstract}
From the research we can conclude that marketing of floriculture is very important but insufficient in Kosovar businesses. The flower market in Kosovo is still not cheap at all, but it has to be said that it has recently made great strides in this direction. In practice, there are cases when individuals and businesses are not widely dedicated after marketing to expand businesses, although almost everyone thinks marketing is very important in this regard, as through marketing, consumers are introduced to the types of flowers that can meet their demands and desires. In general, the factors that have a profound impact on the floricultural market are: marketing and dedication to flowers, improving the different types of flowers, vertical integration of farms and finding new revenue alternatives that would affect profit growth, which is the purpose of any business. The application of advanced marketing, market research, increased assortment, variety differentiation and promotion, is almost incomplete in floricultural businesses. Businesses should be organized to take concrete measures in defense of their interests in the framework of deepening partnership with the Government of the country, to have adequate participation in the country's policymaking institutions. From the results we conclude that $60 \%$ of the respondents stated that the information on the sale of flowers is taken from social networks. Kosovar ornamental plant makers devote marketing importance to $27 \%$, respondents think that applying marketing in the flower business brings benefits up to $86 \%$, in the expansion of the flower market the quality is very important factor $92 \%$ of respondents were declared.
\end{abstract}

Keywords: flower, Industry in floricultura, marketing, Kosovo. 